\title{
UPAYA PEMBERANTASAN NYAMUK AEDES AEGYPTI \\ DENGAN PENGASAPAN (FOGGING) DALAM RANGKA MENCEGAH PENINGKATAN KASUS DEMAM BERDARAH
}

\author{
Yuli Kusumawati, Dwi Linna Suswardany, Saudin Yuniarno, \\ dan S. Darnoto \\ FakultasIlmu Kedokteran \\ Universitas Muhammadiyah Surakarta
}

\begin{abstract}
Dengue Haemoragic Fever is one of infectious diseases which can cause death. The spreading of this disease is caused by Aedes aegypti biting that carries Dengue Virus in its body. The importance of the mosquito elimination by fogging is to kill adult mosquitoes which contain Dengue Virus and are ready to infect ather people. So that the spreading cahin can be severed.The elimination of Aedes aegypti done in Hajjah Nuriah Shabran School of Koranic studies showed satisfying result. After evaluating this location, it could be seen that there was no Aedes aegypti, at least its density was decreased. It also could be noticed that the common environment cleanliness was increasing, there was no more Aedes aegypti breeding places and the larvae did not exist any longer. Finally, there is understanding and awareness increasing of the school of Kuranic Studies members in taking care of environment cleanliness properly to eliminate mosquito and the Aedes aegypti breeding places.
\end{abstract}

Kata kunci: pelatihan, kemampuan kader, penanggulangan DBD

\section{PENDAHULUAN}

Penyakit Demam Berdarah Dengue (Haemorrahigic Fever) merupakan suatu penyakit menular akut yang masih menjadi masalah kesehatan di hampir 27 propinsi di Indoenesia. Hal ini disebabkan, penyakit tersebut penyebarannya sangat cepat dan sering menimbulkan wabah yang luar biasa, sehingga menyebabkan banyak kesakitan bahkan sampai pada kematian.(Anwar, 2000)

Permasalahan ini sering muncul dan berulang bersamaan dengan datangnya musim hujan di negara kita, dan ditunjang kurangnya kesadaran

Upaya Pemberantasan ... (Yuli Kusumawati, dkk.) 1 
akan kebersihan lingkungan dari masyarakat setempat. Kondisi lingkungan sehat merupakan faktor penting atau utama dalam mewujudkan kondisi manusia yang sehat. Penyebaran penyakit demam berdarah dengue sangat ditentukan oleh kondisi lingkungan yang ada.

Lingkungan merupakan salah satu faktor yang sangat berperan dalam timbulnya dan penyebaran penyakit DBD ini. Karena lingkungan kotor sangat berpengaruh terhadap kehidupan dan perkembangan nyamuk yang menjadi perantara. Nyamuk Aedes aegypti bersifat antropofilik yaitu senang menghisap darah manusia. Nyamuk betina biasanya menggigit di dalam rumah, kadangkadang di luar rumah dan ditempat yang agak gelap. Pada malam harinya nyamuk beristirahat dalam rumah pada benda-benda yang digantung seperti pakaian, kelambu, dan tempat-tempat lain yang terlindung, juga di dalam sepatu. Nyamuk ini mempunyai kebiasaan menggigit orang secara bergantian dalam waktu singkat. Hal ini disebabkan karena nyamuk Aedes aegypti sangat sensitif dan mudah terganggu. Keadaan ini sangat membantu nyamuk Aedes aegypti dalam memindahkan virus dengue ke beberapa penderita demam derdarah atau DHF di satu rumah. (Ditjen P3M, DepKes, 1987)

Kehidupan nyamuk Aedes aegypti sangat dipengaruhi oleh lingkungan, baik biologis maupun fisik. Pengaruh lingkungan biologik misalnya berupa air yang lama disimpan dalam container, biasanya akan terdapat patogen dan parasit yang mempengaruhi pertumbuhan larva nyamuk. Sedangkan pengaruh fisik dapat berupa tata rumah, macam container, ketinggian tempat dan iklim. Pengaruh yang lain misalnya berupa pengaruh hujan, yang dapat menyebabkan kelembaban naik dan menambah jumlah tempat perindukan. Kasus demam berdarah dengue lebih cenderung meningkat selama musim hujan. (Daenur, 1992)

Menurut Anwar (2000), bahwa faktor-faktor risiko yang mempengaruhi terjadinya penyakit demam berdarah dengue antara lain: (1) tingkat pengetahuan tentang tanda atau gejala; (2) cara penularan dan pencegahan penyakit DBD; (3) kebiasaan tidur siang; (4) kebiasaan menggantung pakaian; (5) kebiasaan membersihkan tempat penampungan air; (6) kebiasaan membersihkan halaman disekitar rumah; (7) tempat penampungan air didalam atau diluar rumah yang terbuka; dan (8) tempat penampungan air didalam atau diluar rumah yang positif jentik. Semua factor-faktor tersebut menunjukkan adanya hubungan yang signifikan dengan kejadian DBD. 
Pondok Pesantren Hajjah Nuriyah Shabran yang terletak di Desa Makamhaji merupakan salah satu pondok pesantren di Kabupaten Sukoharjo. Seperti pondok pesantren lainnya, pondok pesantren Hajjah Nuriyah Shabran juga merupakan tempat umum yang dihuni oleh banyak orang (santri), dan merupakan bentuk kelompok masyarakat kecil yang hidup atau tinggal bersama.

Sementara itu, image yang selama ini berkembang di masyarakat bahwa pondok pesantren merupakan tempat kumuh, kondisi lingkungannya tidak sehat, dan pola kehidupan yang ditunjukkan oleh santrinya sering kali kotor, lusuh, sama sekali tidak menunjang pola hidup yang sehat. Kondisi seperti ini sangat memungkinkan terjadinya penularan penyakit demam berdarah tersebut dari luar pondok ke dalam pondok, apabila para santri dan pengelolanya tidak sadar agar menjaga kebersihan lingkungan baik di dalam maupun diluar gedung atau lingkungan pondok.

Demikian pula, di pondok Hajjah Nuriyah Shabran yang dihuni oleh lebih 200 santri dari berbagai daerah di Indonesia ini, kondisi lingkungannya juga tidak sehat, dan pola hidup para santrinya tidak menunjukkan pola hidup yang sehat. Biasanya setelah musim hujan dating, terjadi genangan-genangan air di lingkungan atau halaman pondok baik di luar maupun di dalam pondok. Para santri biasanya banyak yang menggantungkan pakaian terutama pakaian kotor, sehingga akan menjadi sarang nyamuk. Berdasarkan survey awal yang dilakukan oleh tim pengabdian menunjukkan bahwa secara umum pengetahuan santri tentang kebersihan lingkungan dan pola hidup sehat masih kurang, termasuk yang berkaitan dengan pencegahan dan penanggulangan penyakit demam berdarah. Kondisi lingkungan yang tidak menunjang dan pengetahuan para santrinya yang kurang tersebut, akhirnya di pondok ini setiap tahunnya terjadi kasus penyakit demam berdarah yang diderita para santrinya. Menurut wawancara yang dilakukan oleh tim pengabdian menunjukkan bahwa hamper setiap tahun sejak mulai tahun 1998 hingga 2003, di pondok ini pasti terjadi kasus DBD minimal ada 3 - 4 santri yang sakit DBD. Oleh karena itu, pemahaman tentang hal tersebut juga sangatlah diperlukan.

Memperhatikan keadaan tersebut, sebagai tempat yang potensial sekali untuk terjadinya penularan penyakit demam berdarah, maka dipandang perlu adanya upaya pemberantasan nyamuk dan sarang nyamuk Aedes aegypti disertai peningkatan pengetahuan tentang pencegahan penyakit ini bagi para santri di Pondok Pesatren tersebut. Sehingga apabila santri di bekali

Upaya Pemberantasan ... (Yuli Kusumawati, dkk.) 3 
pengetahuan tentang pencegahan penyakit tersebut dan lingkungannya dilakukan pembersihan dan pemberantasan nyamuk Aedes aegypti, maka diharapkan penyakit demam berdarah dengue tidak menjangkiti warga pondok dan sekitarnya dan para santri akan sehat serta dapat belajar dengan baik.

Berdasarkan paparan tersebut diatas, dapat dirumuskan suatu masalah yakni:

Sejauh mana pengetahuan warga pondok pesantren Muhamadiyah Hajjah Nuriah Shabran tentang upaya pemberantasan nyamuk Aedes aegypti dan bagaimanakah upaya pemberantasan nyamuk Aedes aegypti yang di lakukan di pondok pesantren Muhamadiyah Hajjah Nuriah Shabran?

Adapun tujuan dari kegiatan pengabdian pada masyarakat ini adalah untuk meningkatkan pengetahuan para santri di pondok pesantren Muhammadiyah Hajjah Nuriyah Shabran tentang penyakit demam berdarah dengue dan upaya pemberantasan nyamuk Aedes aegypti yang menjadi perantara penyebaran dari penyakit DBD tersebut. Upaya pemberantasan nyamuk tersebut dilakukan dengan cara pengasapan (fogging).

Berdasarkan tujuan di atas, maka manfaat yang diharapkan dari kegiatan pengabdian masyrakat ini adalah terjadinya kondisi lingkungan yang sehat di sekitar pondok, pola hidup santri yang menunjang kesehatan, dan tidak lagi dijumpai kasus penyakit DBD bagi penghuni atau santri di pondok tersebut. Pada akhirnya, para santri dapat hidup nyaman dan sehat sehingga dapat mengikuti proses belajar mengajar secara maksimal. Bagi tim pengabdian atau dosen di Fakultas ILmu Kesehatan, kegiatan pengabdian ini merupakan sarana untuk penerapan dan pengembangan ipteks yang berkaitan dengan kesehatan lingkungan, yang sekaligus sebagai pelaksanaan Tri Darma Perguruan Tinggi, dalam rangka ikut menciptakan kesejahteraan bagi masyarakat secara luas, dan khususnya bagi masyarakat di pondok pesantren Muhammadiyah Hajjah Nuriyah Shabran maupun masyarakat di sekitar pondok.

\section{METODE KEGIATAN}

Dalam rangka mencapai tujuan yang diharapkan, maka metode yang dilakukan dalam kegiatan pengabdian masyarakat ini adalah penyuluhan dan diskusi tentang berbagai hal yang berkaitan dengan penyakit demam berdarah dengue, termasuk cara pemberantasannya. 
Sebelum dilakukan penyuluhan bagi para santri yang menjadi sasaran pengabdian ini dilakukan pretes terlebih dahulu. Pertanyaan pretes disampaikan secara lisan dan para santri juga menjawab secara lisan. Materi pertanyaan yang disampaikan berhubungan dengan lingkungan sehat, penyakit demam berdarah dengue, dan cara mengatasi atau memberantas penyakit demam berdarah tersebut.

Setelah dilakukan pretes, kemudian dilakukan action (tindakan langsung) tentang cara pemberantasan nyamuk aedes aegypti dengan pendekatan fogging atau pengasapan yang dilakukan di komplek pondok Hajjah Nuriayah Shabran. Sedangkan seluruh bahan yang dipakai terdiri dari Malathion 2 liter, Solar 40 liter dan Bensin 12 liter. Action, juga dilakukan untuk menciptakan kondisi lingkungan yang bersih dan sehat di komplek pondok tersebut.

Pada akhir kegiatan, dilakukan postes bagi para santri yang tujuannya untuk melihat peningkatan pengetahuan para santri tentang hal-hal yang berhubungan dengan demam berdarah dengue dan lingkungan sehat. Hasil postes tersebut kemudian dijadikan bahan atau dasar untuk melakukan evaluasi kegiatan pengabdian masyarakat.

\section{HASIL DAN PEMBAHASAN}

Hasil kegiatan pengabdian yang berkaitan dengan tingkat pengetahuan santri tentang penyakit demam berdarah dengue, cara pemberantasannya, dan kondisi lingkungan sehat, ternyata setelah dilakukan penyuluhan dan diskusi menunjukkan adanya peningkatan sebesar $55 \%$. Hal ini berarti, pengetahuan para santri tentang penyakit demam berdarah, cara pemberantasannya, dan upaya menciptakan kondisi lingkungan sehat yang semula kecil, kemudian meningkat sebesar 55 tersebut. Hal tersebut sekaligus menunjukkan bahwa para santri sangat serius dan mensikapi positip terhadap upaya untuk meningkatkan pengetahuannya tentang penyakit demam berdarah dengue dan bagaimana cara pemberantasannya.

Namun, untuk tindakan pemberantasan nyamuk dengan pendekatan pengasapan atau foging, pada hari pertama sampai seminggu masih menunjukkan hasil yang efektif. Artinya sampai dengan waktu seminggu, populasi nyamuk masih ada meskipun kecil, namun setelah seminggu populasi nyamuk meningkat lagi hampir sama seperti kondisi awal saat sebelum dilakukan pengasapan. Hal ini dapat disebabkan oleh beberapa faktor, antara

Upaya Pemberantasan ... (Yuli Kusumawati, dkk.) 5 
lain karena secara teknis para santri belum pengalaman melakukan pengasapan sehingga asap tidak merata dan kurang menjangkau daerah atau titik-titik rawan yang menjadi sarang bertelurnya nyamuk.

Pemberantasan nyamuk Aedes aegypti dengan fogging (pengasapan) pada mulanya dianggap oleh masyarakat sebagai cara yang paling tepat untuk mengatasi masalah penyakit demam berdarah. Hal tersebut ternyata tidak selalu benar, karena pemberantasan nyamuk Aedes aegypti dengan metode ini hanyalah bertujuan untuk membunuh nyamuk dewasa yang infektif, yaitu nyamuk yang di dalam tubuhnya telah mengandung virus dengue dan siap menularkan pada orang lain. Sedangkan cara mengatasi / mencegah terjangkitnya penyakit Demam Berdarah Dengue yang paling penting adalah menanamkan pengetahuan terhadap masyarakat, agar masyarakat berperilaku hidup sehat, yaitu menjaga kebersihan lingkungan yang dapat menjadi sarang \& tempat berkembangbiaknya vektor penyakit termasuk nyamuk Aedes aegypti. Hal ini dilakukan untuk memutus rantai penularan penyakit, yaitu memutus mata rantai perkembangbiakan jentik nyamuk menjadi nyamuk dewasa.

Dengan demikian, meskipun tindakan pengasapan untuk memberantas nyamuk kurang berhasil, akan tetapi dengan melihat peningkatan pengetahuan para santri tentang penyakit DBD dan cara pemberantasannya serta upaya menciptakan kondisi lingkungan yang sehat, maka diharapkan ada perubahan perilaku yang ditunjukkan oleh para santri dengan melakukan upaya - upaya hidup sehat, menciptakan kondisi lingkungan yang sehat dalam rangka untuk mencegah timbulnya wabah dan penularan penyakit DBD tersebut.

Berdasarkan laporan dari masyarakat kampung Makam Haji, maupun data dari Puskesmas Kartosuro, bahwa di desa tersebut penyakit Demam Berdarah telah menjangkiti masyarakat. Oleh karena itu, untuk mencegah peningkatan kasus dan penularan ke daerah lain, maka dilakukan upaya memutus rantai penularan dengan melakukan pemberantasan nyamuk Aedes aegypti dewasa dengan metode pengasapan atau fogging agar nyamuk dewasa mati dan dengan disertai upaya menciptakan kondisi lingkungan yang sehat disekitar komplek pondok pesantren.

Pada perkampungan Makam Haji , fogging telah dilaksanakan oleh instansi yang berwenang yaitu Puskesmas. Pondok Petantren Hajjah Nuriah Shabran, yang juga terletak di Desa Makam Haji, merupakan suatu komunitas masyarakat yang dapat juga terjangkiti oleh penyakit demam berdarah. Oleh 
karena itu, untuk menanggulangi supaya warga pondok pesantren tidak tertular, maka dilakukan pula pemutusan mata rantai penularan penyakit demam berdarah, yaitu dengan pemberantasan nyamukAedes aegypti dewasa dengan fogging dan pembersihan sarang nyamuk.

Sebelum pelaksanaan fogging, para santri baik putra maupun putri telah diberikan pengarahan sekaligus pada waktu memberikan penyuluhan untuk menanamkan pengetahuan yang benar tentang seluk beluk penyakit demam berdarah. Pengarahan tersebut berupa persiapan untuk menutup barangbarang yang ada di ruangan supaya pada waktu pelaksanaan foging tidak terkena percikan obat pemberantas nyamuk tersebut. Juga himbauan untuk meninggalkan ruangan/keluar dari ruangan saat dilaksanakan fogging. Hal ini untuk menghindari terjadinya keracunan oleh obat fogging terhadap manusia dan hewan piaraan secara langsung, maupun melalui makanan yang tidak ditutup di tempat tersebut.

Setelah dilakukan evaluasi terhadap lokasi yang telah dilakukan pengasapan / fogging, terlihat bahwa di pondok putra maupun pondok putri telah kelihatan bersih tidak ada lagi jentik-jentik nyamuk di tempat-tempat penampungan air, juga tidak ada lagi tempat-tempat yang dapat menjadi sarang nyamuk serta nyamuk dewasa juga tidak terlihat lagi.

Pelaksanaan pengabdian masyarakat secara keseluruhan dapat berjalan dengan lancar, karena faktor-faktor yang mendukung dalam kegiatan ini , antara lain adanya kerja sama yang baik antara warga pondok dan pelaksana fogging terutama dalam persiapan ruangan yang akan di fogging dan pemahaman warga pondok terutama pondok putri, yang bersedia untuk keluar ruangan saat pelaksanaan fogging.

Namun demikian ada beberapa hambatan yang ada, terutama pada pondok putra, yaitu kurangnya kesiapan warga pondok putra dalam pelaksanaan sehingga menyebabkan pelaksanaan kegiatan pengabdian agak terhambat. Pada saat pelaksanaan fogging ada sebagian santri yang masih ada di dalam ruangan, membahayakan kesehatan dan memperlambat jalannya pengasapan.

\section{SIMPULAN DAN SARAN}

Hasil pelaksanaan kegiatan pengabdian ini dapat disimpulkan sebagai berikut : upaya pemberantasan nyamuk Aedes aegypti dengan metode pengasapan / fogging sebenarnya bukan upaya yang efektif untuk menaggulangi

Upaya Pemberantasan ... (Yuli Kusumawati, dkk.) 7 
penyakit demam berdarah. Namum demikian upaya ini merupakan upaya yang harus dilakukan, apabila telah terjadi adanya kasus / penderita penyakit demam berdarah di wilayah Makam Haji. Hal ini dilakukan terutama untuk membunuh nyamuk dewasa yang telah mengandung virus dengue hasil gigitan dari penderita , untuk ditularkan ke orang lain. Pemberantasan dengan metode ini efektif dilakukan pada jam 07.00 sampai 10.00, yaitu pada jam-jam nyamuk sedang bekerja mencari mangsa. Obat pemberantas nyamuk dengan metode pengasapan / fogging ini dapat bertahan selama kurang lebih 3 bulan sehingga dapat mencegah munculnya nyamuk dewasa. Dengan demikian dapat mencegah adanya peningkatan kasus / penderita.

Berdasarkan hasil kegiatan fogging tersebut, maka saran yang dapat diberikan terutama perlu adanya komitmen kerjasama dengan semua pihak dalam masyarakat dengan warga pondok pesantren dalam upaya memutus rantai penularan penyakit yaitu dengan memutus rantai kehidupan nyamuk Aedes aegypti. Upaya yang paling baik adalah menjaga kebersihan lingkungan agar tidak menjadi tempat perindukan/ sarang nyamuk dan perkembangbiakan nyamuk tersebut. Upaya yang baik harus dilakukan secara teratur dan, yaitu menguras bak mandi minimal seminggu sekali, menutup tempat-tempat penampungan air, menimbun barang-barang bekas yang dapat menjadi tempat perindukan / sarang nyamuk Aedes aegypti.

\section{UCAPAN TERIMA KASIH}

Pada kesempatan inikami mengucapkan terimakasih kepada semua pihak yang terkait, terutama kepada Bapak Rektor UMS melalui Lambaga Pengabdian Masyarakat yang telah berkenan membiayai sehingga kegiatan ini berjalan denga baik. Tak lupa kepada Dekan Fakultas Ilmu Kesehatan yang turut memperlancar kegiatan ini. Ucapan terima kasih kami sampaikan juga kepada Direktur Pondok Pesantren Hajjah Nuriah Shabran, Makam Haji Kartosuro, yang telah memberikan izin untuk lokasi pengabdian.

\section{DAFTAR PUSTAKA}

Depkes R.I , Dit. Jen PPM dan PLP, 1995, Pokok-pokok Kegiatan dan Pengelolaan Gerakan Pemberantasan Sarang Nyamuk Demam Berdarah Dengue (PSN-DBD), Jakarta. 
Dit Jen PPM dan PLP, 1992, Pemberantasan Nyamuk Penularan Penyakit Demam Berdarah Dengue, Jakarta.

Penyakit Demam Berdarah Dengue, Jakarta.

Fooging Massal, Jakarta.

Dainur, 1992, Ilmu Kesehatan Masyarakat, Widya Medika, Cetakan I, Jakarta.

M. Choirul. A., 2000, Faktor-faktor Yang Berhubungan dengan Tingginya Kejadian DBD di Kabupaten Tegal. , Buletin Keslingmas No 73,74 Tahun XX, AKL Depkes, Purwokerto. 
10 WARTA, Vol .10, No. 1, Maret 2007: 01 - 09 
